\title{
Ecology of Heterotrophic Microflagellates. I. Some Important Forms and Their Functional Morphology
}

\author{
T. Fenchel \\ Department of Ecology and Genetics, University of Aarhus, Ny Munkegade, DK-8000 Aarhus C, Denmark
}

\begin{abstract}
Six species of nanoplanktonic, heterotrophic flagellates are described with special reference to feeding mechanisms and functional morphology. Two different types of food particle concentration mechanisms are found: filtration and direct impact. Both mechanisms depend on the creation of water currents. Crude models show that at least in some cases, the described mechanisms can explain experimentally determined values of clearance and that the organisms may subsist on the basis of bacterial concentrations found in seawater Theoretical considerations and previous experimental results render it very unlikely that uptake of dissolved organic material plays any role for these organisms in nature. It is finally argued that organisms of the studied size range ( 3 to $7 \mu \mathrm{m})$ constitute a necessary link between bacteria and larger phagotrophic organisms in planktonic food chains.
\end{abstract}

\section{INTRODUCTION}

Small (3 to $7 \mu \mathrm{m}$ ) heterotrophic flagellates are omnipresent in aquatic environments. During the last decade, several authors have suggested that they may play a large role in planktonic food chains (Pomeroy and Johannes, 1968; Sorokin, 1977; Sieburth et al., 1978; Haas and Webb, 1979; Sieburth, 1979). While there have been attempts to quantify this fauna (Lighthart, 1969; Throndsen, 1969; Chretiennot, 1974), such studies alone have not revealed the ecological significance of these organisms. A much larger amount of literature deals with species lists from water samples. In particular, since forms which carry siliceous spines or loricae, notably choanoflagellates, lend themselves well to observation in a dried state on formvar films in the electron microscope, knowledge has accumulated on the diversity and distribution of such forms in the sea or as contaminants in algal cultures (e.g. Pringsheim, 1963; Lucas, 1968; Leadbeater, 1972a, b, 1974; Pennick and Clarke, 1972; Thomsen, 1973, 1975, 1976; Throndsen, 1974). In addition, there exists some older literature on such flagellates, particularly those appearing in enrichment cultures (Griessmann, 1914; Ellis, 1929; Ruinen, 1938). Finally, in the protozoological literature there are a number of thorough finestructural studies on some representatives of the diffe- rent groups, including scattered observations on life cycles and food uptake (e.g. Laval, 1971; Swale, 1973; Leadbeater and Morton, 1974; Mignot, 1974; Moestrup and Thomsen, 1976; Eyden, 1977; Leadbeater, 1977) Sleigh (1964) described feeding currents in four types of flagellates.

However, all this literature had little impact on the understanding of the role of these organisms in the sea. The reason is mainly a technical one. Due to their small size, they are difficult to observe and their taxonomic affinities and structural properties can often only be made out with the aid of the electron microscope. For experimental purposes, they neither lend themselves to bacteriological techniques; nor can they be manipulated individually like ciliates or representatives of the meiofauna. The heterotrophic microflagellates are in reality a heterogeneous assemblage of in part completely unrelated eukaryotes, including as the quantitatively most important groups the choanoflagellates, a variety of non-pigmented or facultatively phototrophic chrysomonads, related bicoecids, kinetoplastids, non-pigmented euglenoids and dinoflagellates, and the systematically somewhat obscure helioflagellids. Common to them all is only their size and the fact that they are phagotrophic predators on bacteria.

This paper is the first in a series treating the ecology 
of microflagellates. Following papers (Fenchel, $1982 \mathrm{a}, \mathrm{b}, \mathrm{c})$ will treat growth and bioenergetics, adaptations to heterogeneous environments, their qualitative and quantitative distribution and role as bacterial consumers in nature. The present paper gives a description of the functional morphology with special reference to food uptake for 6 different representatives of microflagellates. The same species have been used for experiments in the following papers. Also the marine forms described in the present paper or very closely related forms often constitute more than $50 \%$ of the individuals in a marine plankton (Fenchel, 1982c) and so warrant a closer description, which is necessary in order to understand their role in nature.

\section{MATERIALS AND METHODS}

\section{Materials}

The present paper deals with 2 freshwater and 4 marine species; the limnic forms, however, do not in principle differ from closely related marine forms. All the species were isolated from enrichment cultures (water samples with a wheat grain or similar in order to enhance bacterial growth). Through several generations of cultures based on dilution series and using sterile transfer technique, clonal cultures of the individual species were eventually obtained. Stock cultures consisted of $20 \mathrm{ml}$ sea- or pond water autoclaved with a wheat grain and kept at $15^{\circ} \mathrm{C}$. These cultures were transferred every 1 to 2 mo. For observations and experiments, cultures were rendered monoxenic. Very small inoculates were added to suspensions of a single species of bacteria. By repetition of this procedure a number of times cultures assumed to be monoxenic on the basis of microscopy, were obtained. These cultures must be transferred every 3 to $4 \mathrm{~d}$ at $20^{\circ} \mathrm{C}$. As medium for these cultures, aged, filter-sterilized seawater (25\% S) - or for limnic forms, a mineral solution ( $\mathrm{NaCl}: 80 \mathrm{mg}, \mathrm{NaHCO}_{3}: 4 \mathrm{mg}, \mathrm{CaCl}_{2} 6 \mathrm{H}_{2} \mathrm{O}: 8 \mathrm{mg}$ in $1 \mathrm{l}$ glass distilled water) - was used. As food bacteria, 2 isolates of Pseudomonas, a marine and a freshwater form respectively, were used. The bacteria were grown on nutrient agar. For use they were scraped off the plates and suspended in sterile water. For mass production of flagellates, batch cultures with $100 \mathrm{ml}$ medium with 0.5 to $2 \times 10^{8}{\text { bacteria } \mathrm{ml}^{-1} \text { were used }}_{i}$ after 2 to $3 \mathrm{~d}$ and according to species and the size of the bacterial inoculate the yield will be $10^{5}$ to $10^{6}$ flagellates $\mathrm{ml}^{-1}$ (Fenchel, 1982a).

Ochromonas sp. and Pleuromonas jaculans Perty were originally isolated from a Paramecium culture. The marine forms Pseudobodo tremulans Griessmann and Paraphysomonas vestita (Stokes) were isolated from seawater samples from Limfjorden off the Rønbjerg Marine Station and Actinomonas mirabilis Kent was isolated from seawater samples from Aarhus Bay. Monosiga sp. was originally isolated by Dr. L. W. Haas from the coast of Virginia, USA; most of the data in the present paper are based on his strain, but later an identical form was isolated from Limfjorden.

\section{Experimental and Observational Techniques}

Observations on live material were carried out with a $100 \times$ phase contrast objective including observations with stroboscopic light (Transistor Strobotorch 1202 D, Dave Instruments Ltd) for the quantification of flagellar beat frequency. Electronic flash microphotographs were made in order to establish flagellar wave form. Swimming velocity was measured by tracing paths of movement with a drawing tubus ('camara lucida') on millimeter paper for known time intervals. For the observation of unsectioned material in the transmission electron microscope, cells were fixed in $2 \%$ isotonic $\mathrm{OsO}_{4}$ solutions, rinsed several times in distilled water and concentrated by centrifugation and drops of the cell suspensions were then allowed to dry on formvar/carbon coated grids. For sectioned material, cells were fixed in isotonic sucrose, phosphate buffered ( $\mathrm{pH} 7.3$ ) glutaraldehyde solutions followed by a post-fixation in $1 \% \mathrm{OsO}_{4}$. Rinsed, concentrated cells were embedded in drops of agar, dehydrated, embedded in WestopaI $W$, sectioned on a LKB-ultratome and the sections were stained in uranyl acetate and lead nitrate. Observations were made with a Zeiss EM 9 microscope operated at $60 \mathrm{KV}$. For scanning electron microscopy cells were fixed in a mixture of $2 \% \mathrm{OsO}_{4}$ and saturated $\mathrm{HgCl}_{2}$ (6:1) and rinsed with distilled water in centrifuge tubes. Concentrated cell suspensions were dropped on stubs, submersed in liquid $\mathrm{N}_{2}$, freeze dried, coated with Au and observed in a Cambridge Stereoscan microscope.

\section{RESULTS}

\section{Ochromonas Wyssotzki}

Species of this genus are well known in biochemical physiology since it is easy to grow and displays a versatile metabolism (for references see Aaronson, 1980). Its morphology is well described in Bouk and Brown (1973). It differs from other forms discussed in this paper by possessing a chloroplast within its nuclear membrane. However, the chloroplasts are extremely small in growing cells (in the light as well as in dark) and grow to some prominence only if starved 

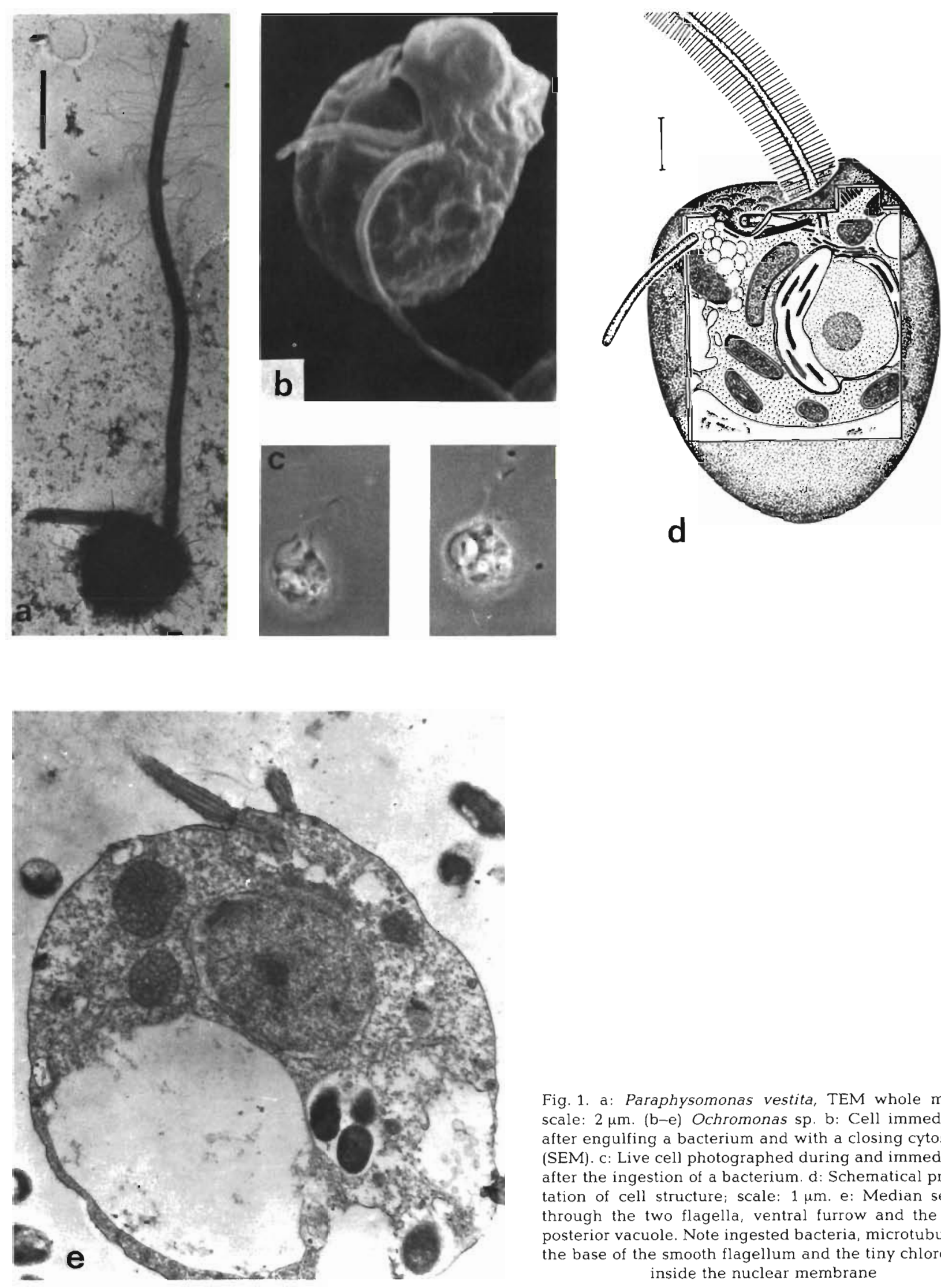

Fig. 1. a: Paraphysomonas vestita, TEM whole mount; scale: $2 \mu \mathrm{m}$. (b-e) Ochromonas sp. b: Cell immediately after engulfing a bacterium and with a closing cytostome (SEM). c: Live cell photographed during and immediately after the ingestion of a bacterium. d: Schematical presentation of cell structure; scale: $1 \mu \mathrm{m}$. e: Median section through the two flagella, ventral furrow and the large posterior vacuole. Note ingested bacteria, microtubules at the base of the smooth flagellum and the tiny chloroplast inside the nuclear membrane 
in the light. It is probably incapable of autotrophic growth (see also Myers and Graham, 1956) and is basically a phagotroph organism. Cells are nearly spherical (Fig. 1) although oblong cells sometimes occur in cultures. Growing cells measure 7 to $7.5 \mu \mathrm{m}$ in diameter. Feeding cells often attach temporarily by a thread-like extension from the posterior end. At the other pole of the cell, 2 flagella emerge, a long (average $18.5 \mu \mathrm{m}$ ) and a short ( 3 to $4 \mu \mathrm{m}$ ) one. The short flagellum is smooth and it normally lies in the ventral furrow parallel to the cytostome. The long flagellum is hispid, that is, it carries 2 rows of hollow mastigonemes (about $9 \mu \mathrm{m}^{-1}$ on either side) and probably oriented parallel to the cytostome and in the plane of the flagellar beat. The flagellum beats in one plane at frequencies of $48-69 \mathrm{~Hz}$. At any time there are bout 2.5 wavelengths per flagellum moving distally and the amplitude of the beat is $0.9 \mu \mathrm{m}$. The resultant water current moves towards the cell and along the ventral furrow. If not attached, this leads to a spiral swimming with a velocity of about $70 \mu \mathrm{m} \mathrm{s}^{-1}$. Bacteria (or other similarly sized particles) in the water current which touch the ventral furrow are phagocytized. This process is probably mediated by the two bundles of microtubules lining the ventral furrow. As a bacterium touches the cell, the right margin of the furrow immediately rises to a $2 \mu \mathrm{m}$ high, concave wall in which the food particle is trapped as the cytostome closes again (Figs. 1, b-c). The entire process takes about $20 \mathrm{~s}$ which is consistent with the fact that the organism can at most ingest some 190 bacteria $\mathrm{h}^{-1}$ (Fenchel, 1982a). During the engulfment process the long flagellum is immobile. Ingested bacteria pass along the right side of the cell and accumulate in posteriorly situated vacuoles where digestion takes place. Eventually these vacuoles merge into a very large vacuole containing egesta (Fig. 1 e).

\section{Paraphysomonas vestita (Stokes)}

The genus Paraphysomonas comprises forms which are extremely closely related to Ochromonas; they differ from the latter by a complete absence of chloroplasts and by a cover of siliceous spines (Fig. 1 a). $P$. vestita was originally described from freshwater but also occur as a marine form. The marine strain pictured in Fig. 1 a and used for experimental studies (Fenchel, 1982a) may in fact be closer to $P$. imperforata Lucas, but the distinction between the two forms is not quite clear (see Thomsen, 1975) and so the name $P$. vestita is retained here. Based on spicule morphology a large number of marine species have been described and they seem to be a constant part of marine plankton (Lucas, 1968; Pennick and Clark, 1972; Leadbeater,
1974; Thomsen, 1975). The feeding process and the associated organelles seem in all respects to be identical to what is found in Ochromonas.

\section{Pseudobodo tremulans Griessmann}

This flagellate was described by Griessmann (1914) from various marine enrichment cultures and apparently refound by Ruinen (1938); otherwise it does not seem to be mentioned in the literature. A form isolated by me from Aarhus Bay and from the Limfjord, where it is a numerous and constant part of the plankton is in all probability identical to Griessmann's organism as based on the original description. The flagellate is some 4 to $5 \mu \mathrm{m}$ in diameter and (trophic) cells are asymetrically built (Fig. 2), There are 2 flagella. A posterior, smooth one passes through a ventral furrow and is used for temporary attachment to particles or the water film. It measures 10 to $16 \mu \mathrm{m}$ and bends at intervals. The long, anterior flagellum is twisted spirally for some $360^{\circ}$ (Fig. 2 b). It is hispid with 1 row of mastigonemes which point inwards in the spiral formed by the flagellum. It beats with a frequency of about $40 \mathrm{~Hz}$ with waves in the plane of the mastigonemes and drives a stream of water toward the cytostome, the right side of which is bordered by a huge lip (Fig. 2 a, c, d, f). This is supported by a bundle of at least 10 microtubules which originate at the base of the large flagellum. A similar bundle of $3 \mathrm{mic}-$ rotubules borders the ventral furrow. Ingestion of bacteria takes place much in the same way as in Ochromonas. This arrangement and other structures seem quite analogous to what is found in Ochromonas and Paraphysomonas, only the peristomal area is greatly extended and the cell has a more pronounced asymmetry. It is in practically all structural details reminiscent of Bicoeca as described by Moestrup and Thomsen (1976) except that bicoecids always have a permanent siliceous lorica; Pseudobodo is perhaps best described as a non-loricate bicoecid. At the onset of starvation, the cells divide twice to form four oblong swarmers with only about $25 \%$ of the cell volume of the trophic cells (Fig. 2 e). These cells never attach, the long flagellum is held straight forward propelling the flagellates while the posterior flagellum trails after.

\section{Monosiga Kent}

This small choanoflagellate ( 3 to $3.5 \mu \mathrm{m}$ in diameter) belongs to the non-loricate Codonosigidae. The morphology of some other choanoflagellates has recently been described in detail by Laval (1971), Leadbeater and Morton (1974) and Leadbeater (1977). The present 

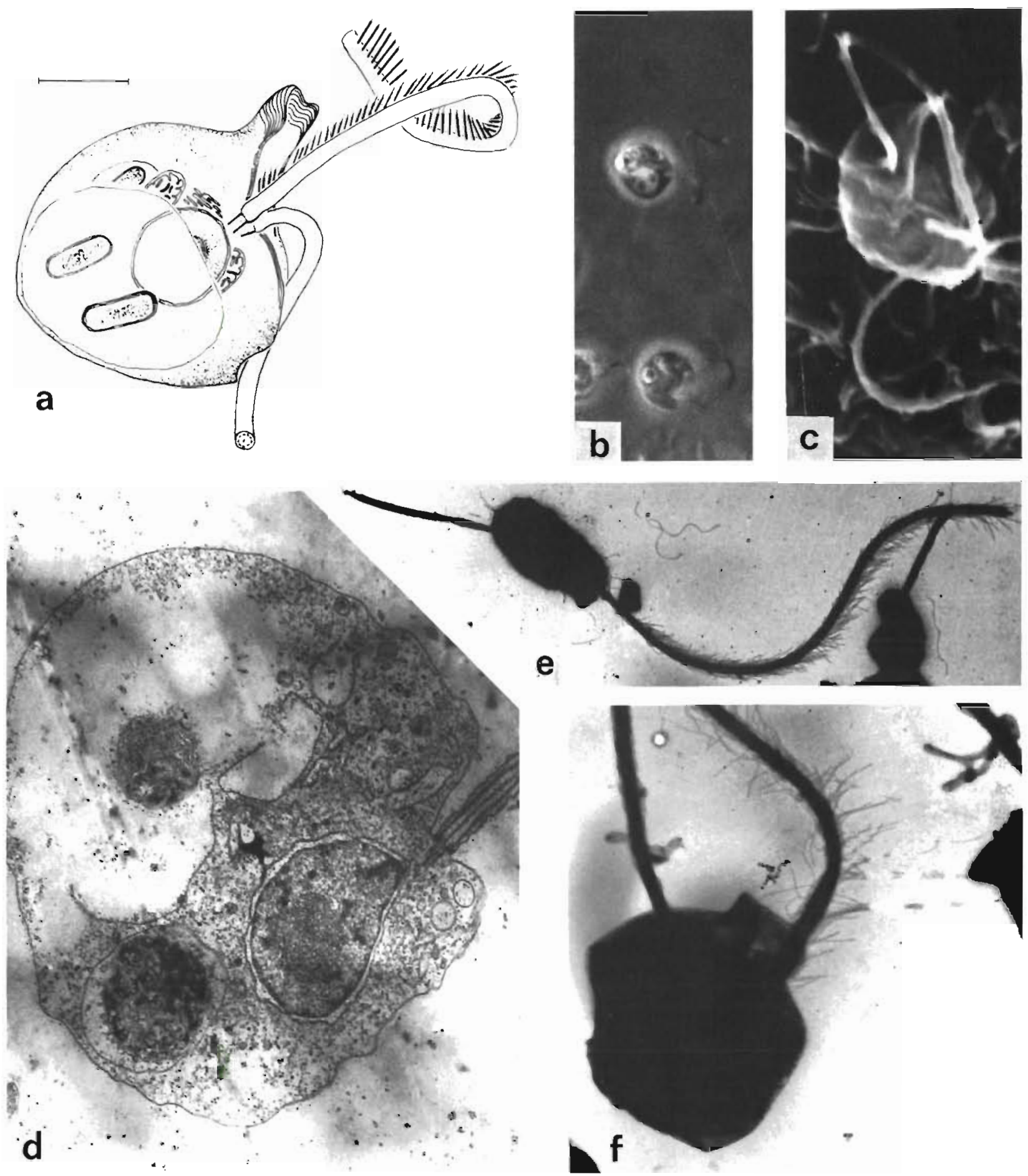

Fig. 2. Pseudobodo tremulans. (a) Schematical presentation of cell structure; scale: $1 \mu \mathrm{m}$. (b) Live cells. (c) Cell viewed with SEM. (d) Oblique section through the large posterior-right vacuole, flagellar furrow with microtubules descending from the mouth, and the posterior flagellum. (e-f) Whole mounts viewed with TEM; e: swarmer, f: trophic cell

findings are in accordance with their results. The central smooth flagellum is 5 to $6 \mu \mathrm{m}$ long, but its peripheral microtubules end about $1 \mu \mathrm{m}$ before the tip giving the flagellum a pointed shape (Fig. 3 a). It is surrounded by a collar consisting of $18,0.1 \mu \mathrm{m}$ thick pseudopodia each containing 2 microtubules which proximally extend into the cytoplasm of the cell. From the base of the flagellum 36 microtubules, two for each 

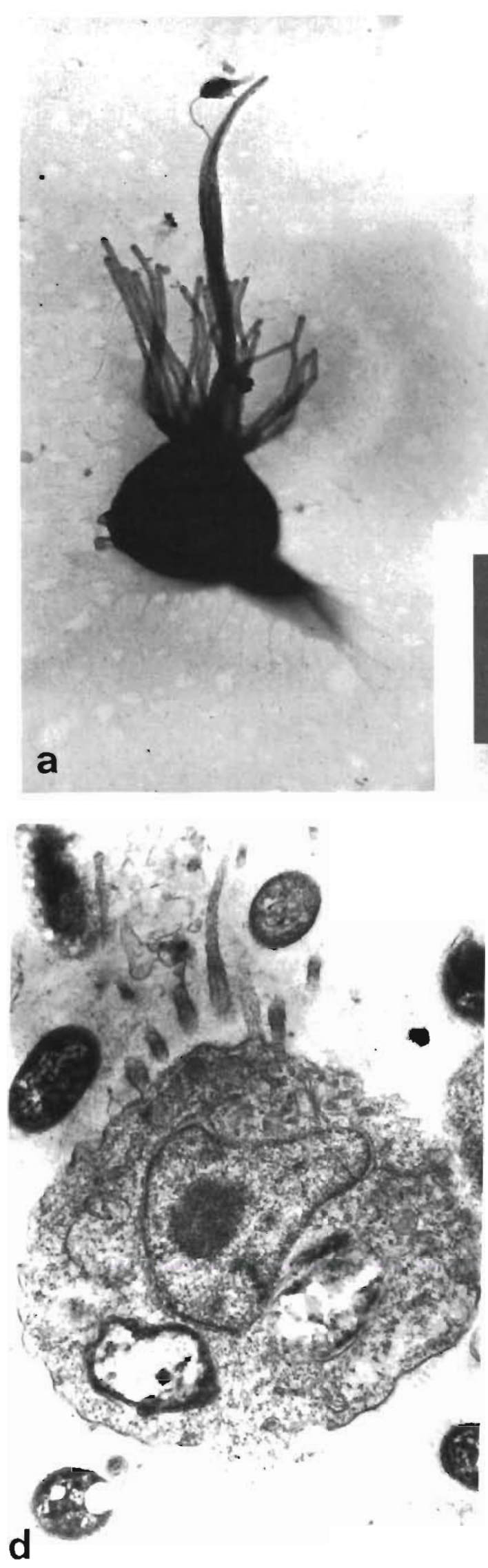
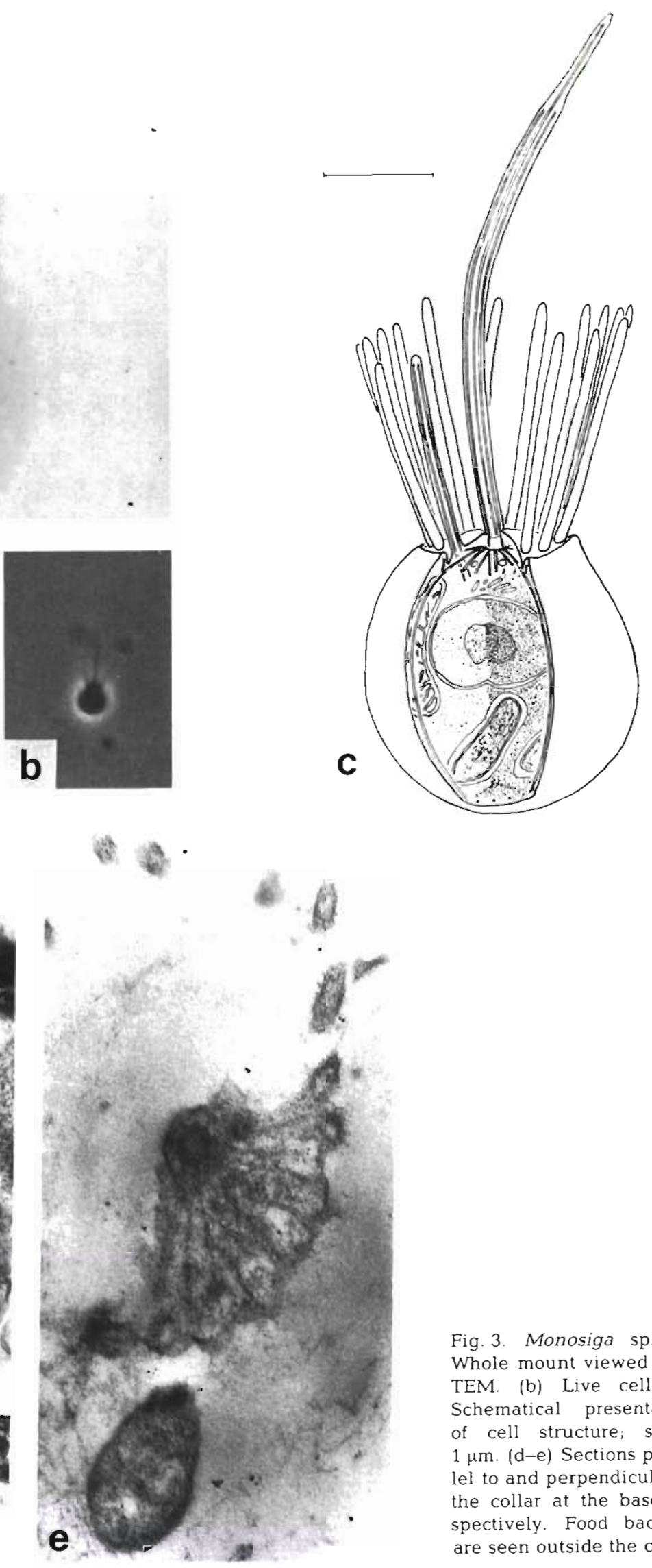

Fig. 3. Monosiga sp. (a) Whole mount viewed with TEM. (b) Live cell. (c) Schematical presentation of cell structure; scale: $1 \mu \mathrm{m}$. (d-e) Sections parallel to and perpendicular to the collar at the base respectively. Food bacteria are seen outside the collar 
pseudopodium, radiate out; they follow the entire cell surface as meridians (Fig. 3 c-e). The diameter of the collar is about $2.5 \mu \mathrm{m}$ distally and about $1.5 \mu \mathrm{m}$ at its base. The entire surface of the collar is $20 \mu \mathrm{m}^{2}$. The free space between adjacent pseudopodia is about $0.25 \mu \mathrm{m}$ at the base increasing to about $0.35 \mu \mathrm{m}$ distally. The flagellum beats at a frequency of 30 to $35 \mathrm{~Hz}$, the wave length is about $6 \mu \mathrm{m}$ and the amplitude around $1 \mu \mathrm{m}$. The flagellum drives water away from the cell and thus draws water through the collar from the outside. As already described by Laval (1971) and by Leadbeater and Morton (1974), food particles are caught on the outside of the collar and engulfed by pseudopodia arising from the peripheral base of the collar. Food bacteria are then transported to the posterior end of the cell. As in Pseudobodo, starving Monosiga form swarmers through two successive divisions; they are ellipsoid in shape, with a volume of only $5 \mu \mathrm{m}$ and are generally, but not always, devoid of a collar.

\section{Actinomonas mirabilis Kent}

The taxonomic position of this organism is somewhat obscure; together with some related forms it is usually placed among the heliozoans within the family Helioflagellidae. My isolate from Aarhus Bay looks much like the form pictured by Griessmann (1914) except that it seems to have fewer pseudopodia. It has been reported from Puget Sound (Lighthart, 1969) and a strain quite identical to mine has been isolated in the Western Atlantic (J. Sieburth, pers. comm.). The organism is spherical or pearshaped with a diameter of 4 to $5 \mu \mathrm{m}$ (Fig. $4 \mathrm{a}, \mathrm{b}$ ). It attaches temporarily with a long stalk of unknown structure. In the anterior end a hispid, $16 \mu \mathrm{m}$ long flagellum arises from the bottom of a depression. There are about 13 mastigonemes $\mu \mathrm{m}^{-1}$ in 2 rows along the flagellum which measure $1.5 \mu \mathrm{m}$ in length. The flagellum beats with a frequency of about $50 \mathrm{~Hz}$, a wave length of $7 \mu \mathrm{m}$ and an amplitude of $1.5 \mu \mathrm{m}$. It drives water towards the cell; the swimming velocity was found to be in the range 180 to $300 \mu \mathrm{m} \mathrm{s}^{-1}$. In the feeding organism, the flagellum is surrounded by 10 to $12,6-\mu \mathrm{m}$ long pseudopodia set at an angle of $45^{\circ}$ from the axis. The diameter of the pseudopodia is about $0.2 \mu \mathrm{m}$ at their bases, but they become more slender distally. The pseudopodial collar forms a sieving apparatus with a surface area of 80 to $120 \mu \mathrm{m}$. The distance between adjacent pseudopodia is ca. $1 \mu \mathrm{m}$ at the base and grows to around $3 \mu \mathrm{m}$ distally. Ingestion of trapped particles must take place in the area between the flagellum and the pseudopodia, but this could not be observed directly. Interiorly, the pseudopodia are supported by microtubules which originate from the nuclear membrane (Fig. 4 d). Within the cell these microtubules are arranged in patterns of 9 double tubules rather like flagellar kinetosomes. At some level there is a central electrondense ring structure in pseudopodia cut perpendicularly. More distally, fewer microtubules occur in the pseudopodia (Fig. 4 e).

\section{Pleuromonas jaculans Perty}

This form represents the flagellate order Kinetoplastida characterized by a unique mitochondrial structure, a swelling containing extranuclear DNA and also by the flagellar structure. Vickerman (1976) questions the systematic position of the then insufficiently studied Pleuromonas, but photographs (Fig. 5) leave no doubt that it is a quite typical representative of kinetoplastids like Bodo and Rhynchomonas (Swale, 1973; Eyden, 1977). The organism is about $4.5 \mu \mathrm{m}$ long and 1.5 to $2 \mu \mathrm{m}$ wide. The 2 flagella emerge from a cavity on the left side of the cell, an anterior hispid, 6 to $8 \mu \mathrm{m}$ long one and a smooth, 14 to $16 \mu \mathrm{m}$ long posterior one which is used for temporary attachment. The cytostome is a structure which leads into a permanent 'pharynx' heavily enforced by microtubular bundles (Fig. 5 c, d). The anterior flagellum drives water past the cytostome and bacteria touching it are phagocytized. It was not possible to study the jerky flagellar movements in detail.

\section{DISCUSSION AND CONCLUSIONS}

The present paper presents examples of different types of heterotrophic nanoplankton flagellates. It is characteristic for all of them that they possess specializations for phagotrophy and for the collection of food particles in the bacterial size range. It will now first be considered whether these mechanisms can, in fact, explain directly measured filtration rates (Fenchel, 1982a)

The acquisition of food particles is somehow a function of the velocity of water currents produced and the area of some 'collector' surface. The water currents are in all cases produced by a single flagellum. As originally explained by Holwill and Sleigh (1967), smooth flagella (Monosiga) will propel water in the direction of the metachronal wave (away from the cell) whereas hispid flagella (the remaining studied species) will propel water in the opposite direction.

When the water flow past the cell is to be estimated, 2 different cases must be considered: freely swimming and attached cells. During swimming, the flagellum itself only creates small, local velocity fields (Lighthill, 1976); the main velocity field relative to the cell is created by the movement of the cell body through the 

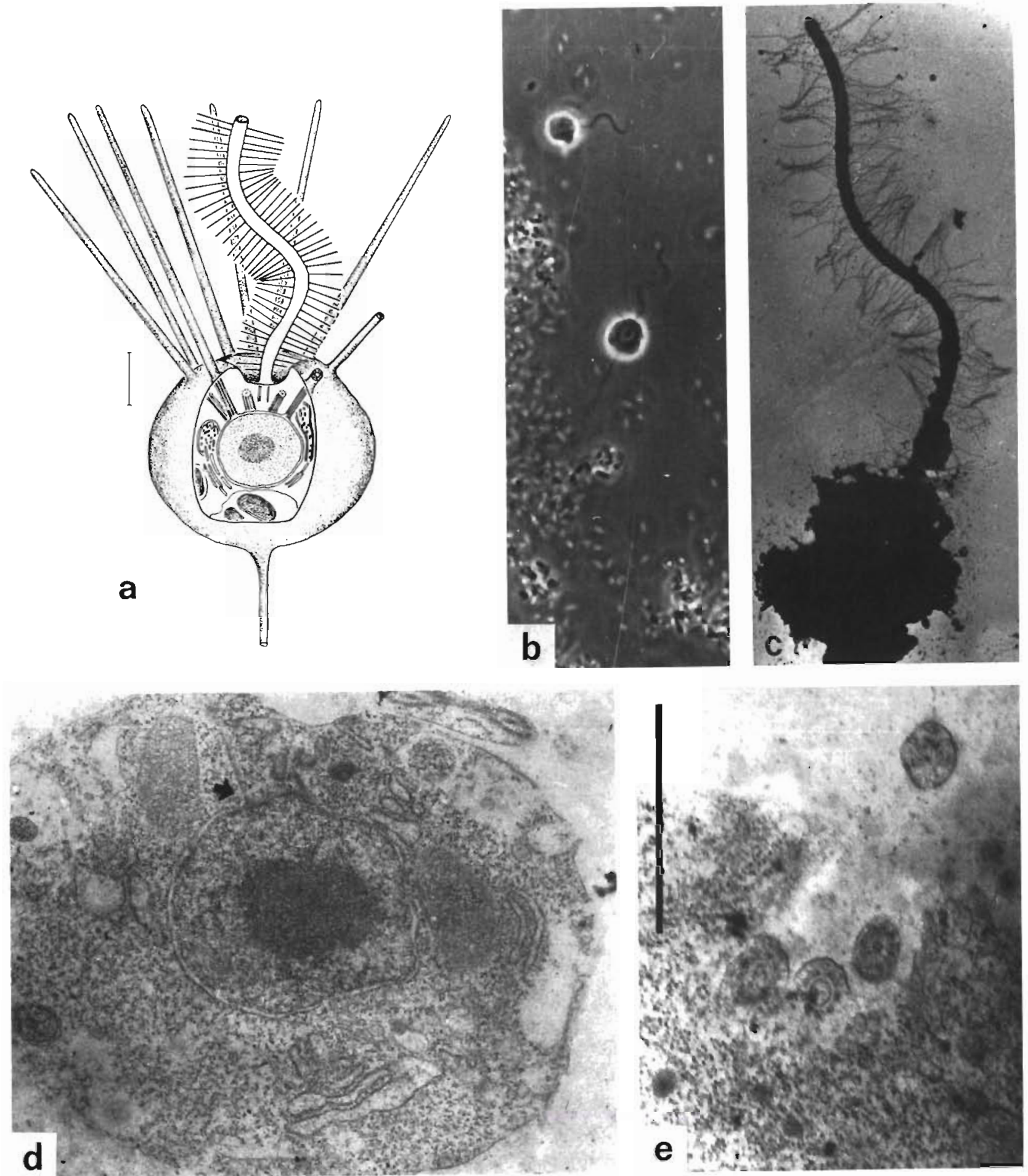

Fig. 4. Actinomonas mirabilis. (a) Schematical presentation of cell structure; scale: $1 \mu \mathrm{m}$. (b) Live cells. (c) Whole mount of flagellum viewed with TEM. (d) Median section showing the microtubular axes of the pseudopodia some of which can be seen to originate at the nuclear membrane (arrow). (e) Cross sections of pseudopodia emerging from the cell; scale: $1 \mu \mathrm{m}$

water. The superficial velocity of the swimming cell (the velocity relative to the far field) can be measured microscopically. Assuming spherical cells, the velocity field around the cell can be calculated from the solu- tion to Stoke's equations with the boundary condition that the water layer at the cell surface remains stationary relative to it (e.g. Roberts, 1981). When the cell is attached, however, the situation is different. Now the 


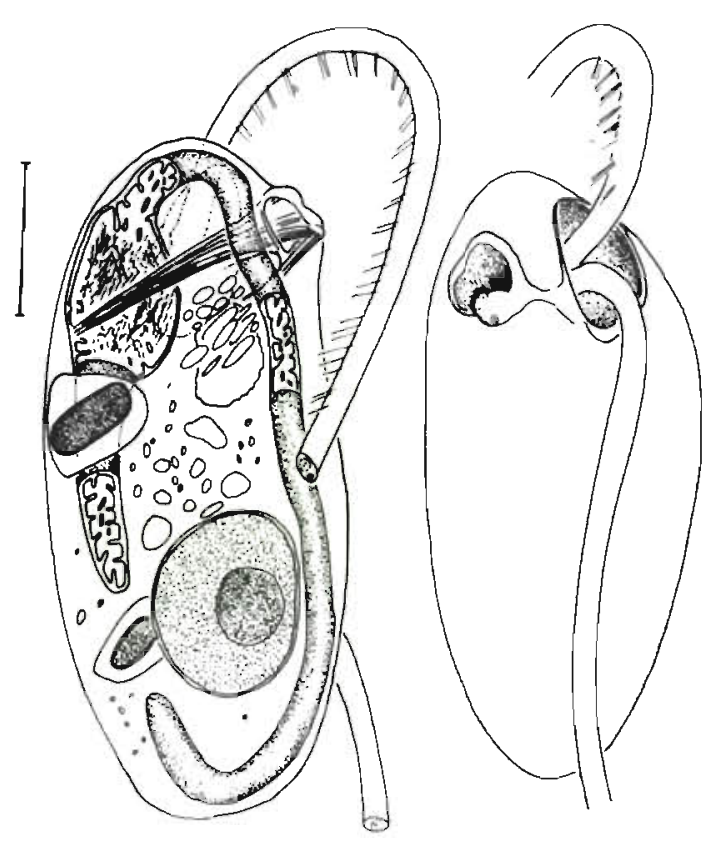

a
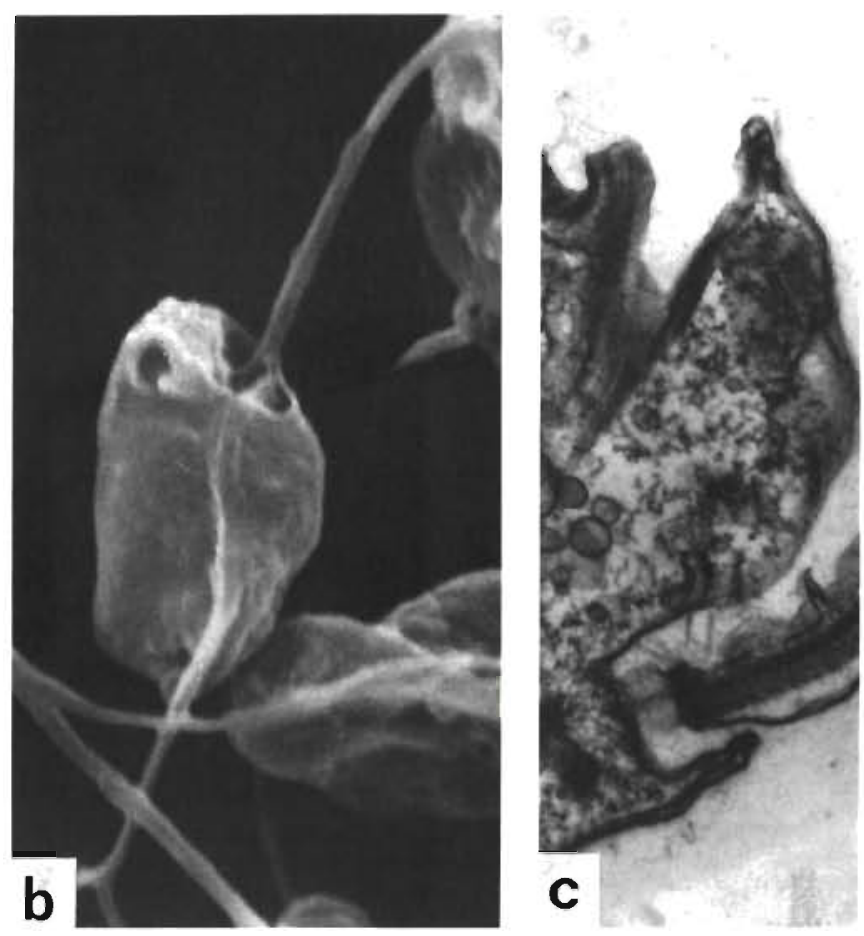

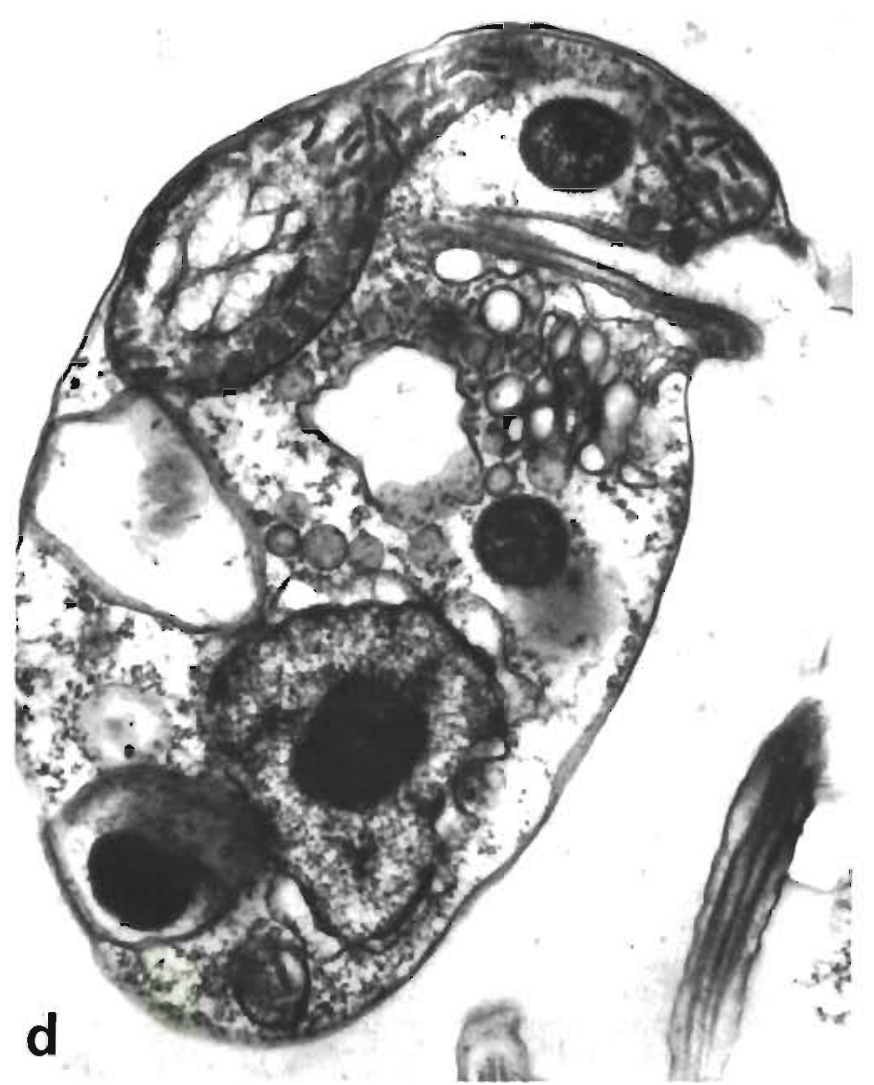

Fig. 5. Pleuromonas jaculans. (a) Schematical presentation of cell structure; scale: $1 \mu \mathrm{m}$. (b) Cell viewed with SEM. (c) Section through flagellar depression and opening of the cytostome. (d) Longitudinal section through cytopharynx, kinetoplast, nucleus, Golgi apparatus, and food vacuoles with bacteria flagellum will create a large scale flow around itself. This flow field can be calculated from the thrust per unit length flagellum which again can be estimated from the swimming velocity and the calculated hydrodynamic drag of an assumed spherical cell with a given radius (Lighthill, 1976). (It is of course assumed 
here that the power output and the parameters describing the flagellar movements remain unchanged whether the cell is swimming or attached). From the calculated flow field, Lighthill (1976) showed that the total water flow, $Q$, through a disc with the radius $R$ and with the center at the base of a flagellum is given by, $Q=T R^{2} / 4 \mu \ln (21 / R)$, where $T=$ thrust per unit unstretched flagellar length, $l ; \mu=$ water viscosity

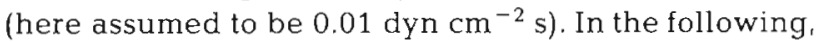
the filtration rate of swimming as well as of attached cells will be considered.

Among the studied forms, 2 types of particle interception can be distinguished: filter feeders (Actinomonas, Monosiga) which depend on a sieving mechanism and the remaining forms which depend on a direct impact with the food particles in the feeding current. In Actinomonas the filter has the shape of a frustrum of a cone with a surface area of up to $120 \mu \mathrm{m}^{2}$ and consisting of pseudopodia extending about 3 times a cell radius and set at an angle of about $45^{\circ}$ relative to the axis of the cell. The swimming velocity (at $20^{\circ} \mathrm{C}$ ) was found to be up to $300 \mu \mathrm{m} \mathrm{s}^{-1}$. We will first consider a swimming cell. Calculating the tangential velocity gradient at $45^{\circ}$ from the axis of the cell (that is normal to the pseudopodia) and integrating this along the length of a pseudopodium yields that the average water velocity through a unit of filter area is about 0.44 times the superficial water velocity. Calculation of the filtration rate then yields $0.44 \times 300 \mu \mathrm{m} \mathrm{s}^{-1} \times 120 \mu \mathrm{m}^{2}$ $=1.58 \times 10^{4} \mu \mathrm{m}^{3} \mathrm{~s}^{-1}$ or $5.7 \times 10^{-5} \mathrm{ml} \mathrm{h}^{-1}$. For the calculation of the filtration rate of an attached cell, on the other hand, it was found that the radius of the circle determined by the distal tips of the pseudopodia is $6.5 \mu \mathrm{m}$. The thrust of the flagellum was calculated as $1.7 \times 10^{-3} \mathrm{dyn}_{\mathrm{cm}}^{-1}$ and from these values a filtration rate of $7.25 \times 10^{-5} \mathrm{ml} \mathrm{h}^{-1}$ could be calculated

These values may be compared with an experimentally determined value of clearance (Fenchel, 1982a) of $7.9 \times 10^{-5} \mathrm{ml} \mathrm{h}^{-1}$ (filtration of bacteria at $20^{\circ} \mathrm{C}$ ). This very close agreement with the calculations for an attached cell may be fortuitous, however, since a number of complications have been ignored. These include the effect of the pseudopodia on the velocity field and the fact, that swimming speed measurements may be influenced by the presence of the coverslip in the microscopical preparations. Yet the argument shows that the necessary magnitude can be achieved by the assumed mechanism.

In Monosiga the swimming velocity is estimated to be around $30 \mu \mathrm{m} \mathrm{s}^{-1}$. However, very reliable estimates could not be obtained since this organism rarely swims in microscopical preparations. Calculations similar to those carried out for Actinomonas yielded for this much smaller flagellate filtration rates of $8 \times 10^{-7}$ and $10^{-6} \mathrm{ml} \mathrm{h}^{-1}$ for swimming and attached cells respec- tively. Experimentally it was found that Monosiga can clear about $2 \times 10^{-6} \mathrm{ml} \mathrm{h}^{-1}$ (Fenchel, 1982a), a value some 3 respectively 2 times higher than the 2 estimates based on hydrodynamical considerations. This discrepancy is probably mainly due to inadequate estimates of swimming velocity and to bacterial motility (see below). Irrespective of the precision of these calculations, it is clear that the water velocity through the filter is much higher in Actinomonas than in Monosiga. This may relate to the lower porosity of the Monosiga collar and hence to a higher pressure drop over the filter (Fenchel, 1980). Actinomonas can probably not retain particles smaller than about $1 \mu \mathrm{m}$ whereas Monosiga is capable of filtering particles down to the size range of 0.2 to $0.3 \mu \mathrm{m}$ and therefore even the smallest prokaryote cells.

The other forms studied all depend on a direct interception between the cell and the food particles. In this case, only particles with their center in the flow lines less than 1 particle radius away from the cell will be intercepted. It is very difficult to make precise models for predicting clearance, but it is intuitively clear that for a spherical organism with a given diameter, filtration rate will fall drastically with decreasing food particle size. This is because the cross sectional area of water flow which can be swept for particles decreases and since the tangential water velocity decreases strongly when approaching the cell surface. This type of feeding can therefore only work if there is some minimum ratio of grazer to food particle sizes. Models generated for spherical collectors in filter beds predict that the interception of particles per collector is simply proportional to the square of the radius of the collected particles so that clearance for a spherical collector would equal $3 / 2 \pi r^{2} v_{0}$ (Spielman, 1977), where $r=$ particle radius; $v_{0}=$ superficial (far field) water velocity. Applying this to a swimming Ochromonas cell $\left(v_{0}\right.$ $\left.=70 \mu \mathrm{m} \mathrm{s}^{-1}\right)$ feeding on bacteria with a mean caliper diameter of $2 \mu \mathrm{m}$ yields $1.2 \times 10^{-6} \mathrm{ml} \mathrm{h}^{-1}$, a value some 8 times lower than experimentally determined values of clearance. Calculations on a stationary cell, assuming that the flagellates can sweep a water flow corresponding to a cylinder with a radius of $2 \mu \mathrm{m}$ and with the flagellum as an axis, yield $3.5 \times 10^{-6} \mathrm{ml} \mathrm{h}^{-1}$ or about $35 \%$ of the measured value of clearance (Fenchel, 1982a). Obviously, the models are too simplified in this case and a number of factors may increase efficiency. These include van der Waals forces and particle rotation in the flow field which may result in the interception of particles further away than the critical flow line discussed above (Spielman, 1977). Movements of the bacteria due to Brownian movements or to cell motility may also enhance the rate of capture (see below). Also, in particular the peristomal area deviates significantly from a spherical shape and 
the efficient particle diameter may be significantly larger than microscopic measurements indicate due to mucus layers. Finally, reservations concerning measurements of swimming velocity apply as above. In particular, Ochromonas swims in a 3 dimensional spiral path rather than along a straight line and so the real swimming velocity may be quite underestimated.

The above calculations confirm the suggestion by Lighthill (1976) that suspension feeding protozoans make more efficient use of flagellar water currents when the organisms anchor themselves to a substrate. This is also supported by the fact that although the studied forms occur in planktonic environments, they all tend to attach to surfaces in cultures with only a fraction of the cells swimming around at any time. This is in contrast to (often related) photosynthetic microflagellates which do not possess adaptations for anchoring themselves. In nature, a very large fraction of the heterotrophic microflagellates are associated with suspended particles in water samples (Fenchel, $1982 \mathrm{C}$ ).

It is sometimes implied that the heterotrophic microprotozoans may play a role as consumers of dissolved organic material (e.g. Beers et al, 1980). However, neither theoretical considerations nor experimental evidence support this. In the sea, low molecular and easily degradable organics occur in very low concentrations, certainly less than $50 \mu \mathrm{g} \mathrm{C}^{-1}$. Under these conditions, uptake is diffusion limited; that is, the capacity of the transport system in the cell membrane is not limiting and the substrate concentration at the cell membrane is nearly zero. Under these conditions, it is a well known result (Koch, 1971; Roberts, 1981) that uptake of a spherical organism will equal $4 \pi \mathrm{RDC}$, where $\mathrm{R}=$ radius of the cell; $\mathrm{D}=$ diffusion coefficient; $\mathrm{C}=$ bulk concentration of the dissolved substrate. Clearance measured in units of cell volume must therefore decrease with the square of cell diameter. Since the flagellates studied have a diameter some 10 times larger than bacteria, they must be 100 times poorer competitors for dissolved organic material. Small protozoans are often grown on dissolved organic material in axenic laboratory cultures; however, very high concentrations must be used. As an example, Myers and Graham (1956) grew Ochromonas in dissolved organics in concentrations of about $10 \mathrm{~g} \mathrm{C}^{-1}$ (mainly as sucrose, but also including a variety of amino acids and vitamins). They found a doubling time of about $14 \mathrm{~h}$. Growing on bacteria, Fenchel (1982a) found that a doubling time of $14 \mathrm{~h}$ for Ochromonas requires a bacterial concentration of about $6 \times 10^{6}$ bacteria $\mathrm{ml}^{-1}$ or about $0.6 \mathrm{mg} \mathrm{C} \mathrm{C}^{-1}$. This means, that Ochromonas is nearly $2 \times 10^{4}$ times more efficient when feeding on particulate food as compared to dissolved organics. Haas and Webb (1979) could not demonstrate any significant uptake of labelled amino acids in concentrations of up to $75 \mathrm{mg} \mathrm{l}^{-1}$ in related flagellates

Finally, returning to the mechanisms involved in the capture of particulate food, the effect of Brownian movement of the bacteria should be considered. A crude evaluation of this effect is easily achieved. For non-motile bacteria (or any other particles of known size) the diffusion coefficient can be estimated from Einstein's relation: $D=k T / 6 \pi \mu R$, where $k=$ Boltzmann's constant; $T=$ absolute temperature; $R=$ particle radius; $\mu=$ water viscocity (Roberts, 1981; Rubinow, 1975). At a temperature of $20^{\circ} \mathrm{C}$, a viscocity of 0.01 Poise and a radius of the (spherical) bacteria of $0.5 \mu \mathrm{m}, D$ would amount to about $5 \times 10^{-9} \mathrm{~cm}^{2} \mathrm{~s}^{-1}$. Using the above equation for the uptake of dissolved organics and dividing it by particle concentration, $C$, yields the expression $4 \pi R D$ as an estimate of maximum clearance by a spherical predator with a radius $R$. For a flagellate with a radius of $5 \mu \mathrm{m}$, this gives about $10^{-7}$ $\mathrm{ml} \mathrm{h} \mathrm{h}^{-1}$, a value 50 to 500 times lower than those actually measured or those estimated from water flow measurements and assuming a filtration mechanism. Hence, Brownian movement probably plays an insignificant role in this case. This picture, however, is changed when motile bacteria are considered. Assume that the bacteria perform three-dimensional random walk with a swimming velocity, $v=30 \mu \mathrm{m} \mathrm{s}^{-1}$ and a mean path length, $l=30 \mu \mathrm{m}$. A diffusion coefficient can then be calculated as $v 1 / 6=1.5 \times 10^{-6} \mathrm{~cm}^{2} \mathrm{~s}^{-1}$. The clearance value for the flagellate would then become about $3 \times 10^{-5} \mathrm{ml} \mathrm{h}^{-1}$, a value of the same magnitude as the measured ones. In the present study, a motile strain of bacteria was used for the experiments with the marine flagellates. In these forms the mechanism may well explain why experimentally determined rates of clearance are somewhat higher than those estimated by assuming the filtration of particles which faithfully follow the flowlines of a velocity field.

Certain facts, however, suggest that in the studied forms this mechanism may not be so important. Sieburth (1979) states that motile bacteria are quantitatively unimportant in marine plankton. Also the morphology and mode of water propulsion of the studied forms suggest that straining of particles in water currents is the dominating mechanism of particle capture. An organism depending on prey motility rather than its own motility would be expected to have a different morphology. It would be capable of taking up food particles on its entire surface (which is assumed in the above calculations) rather than having one, fixed cytostome and it would maximize linear dimensions relative to cell volume (cf. the equation for uptake by diffusion). Such designs are represented, for example, by heliozoans or foraminiferans among the protozoans. 
These forms clearly depend on motile prey which randomly come into contact with a system of long pseudopodia surrounding these organisms.

The present results suggest in a general way that food chain efficiency depends on a limited size ratio between grazers and their food particles. For marine plankton this means that heterotrophic nanoplankton constitute a necessary link between bacteria and larger grazers.

Acknowledgements. I am grateful to Dr. Leonard W. Haas, Virginia Institute of Marine Science for giving me his Monosiga culture. I am indebted to Ms. Annie Solling for invaluable assistance with electron microscopical and photographic work. The study was in part supported by Grant No. 11-0949 from the Danish Natural Science Research Council.

\section{LITERATURE CITED}

Aaronson, S. (1980). Descriptive biochemistry and physiology of the Chrysophyceae (with some comparisons to Prymnesiophyceae). In: Levandowsky, M., Hutner, S. H. (eds.) Biochemistry and physiology of protozoa, 2nd ed., Vol. III. Academic Press, New York, pp. 117-169

Beers, J. R., Reid, M. F. H., Steward, G. L. (1980). Microplankton population structure in Southern California nearshore waters in late spring. Mar. Biol. 60: 209-226

Bouck, G. B., Brown, D. L. (1973). The microtubules, biogenesis and cell shape in Ochromonas. I. The distribution of cytoplasmic and mitotic microtubules. J. Cell Biol. 56: 340-359

Chretiennot, M.-J. (1974). Nanoplancton de flaques supralittorales de la région de Marseille. Protistologica 10: $477-488$

Ellis, W. N. (1929). Recent researches on the Choanoflagellata (Craspedomonadines). Ann. Soc. r. zool. Belg. 60: 49-88

Eyden, B. P. (1977). Morphology and ultrastructure of Bodo designis Skuja 1948. Protistologica 13: 169-179

Fenchel, T. (1980). Relation between particle size selection and clearance in suspension-feeding ciliates. Limnol. Oceanogr. 25: 733-738

Fenchel, T. (1982a). Ecology of heterotrophic microflagellates. II. Bioenergetics and growth. Mar. Ecol. Prog. Ser. 8: 225-231

Fenchel, T (1982b). Ecology of heterotrophic microflagellates. III. Adaptations to heterogeneous environments. Mar. Ecol. Prog. Ser. 9: in press

Fenchel, T. (1982c). Ecology of heterotrophic microflagellates. IV. Quantitative occurrence and importance as consumers of bacteria. Mar. Ecol. Prog. Ser. 9: in press

Griessmann, K. (1914). Über marine Flagellaten. Arch. Protistenk. 32: 1-78

Haas, L. W., Webb, K. L. (1979). Nutritional mode of several non-pigmented microflagellates from York River Estuary, Virginia. J. exp. mar Biol. Ecol. 39: 125-134

Holwill, M. E. J., Sleigh, M. A. (1967). Propulsion by hispid flagella. J. exp. Biol. 42: 267-276

Koch, A. L. (1971). The adaptive responses of Escherichia coli to a feast and famine existence. Adv. Microb. Physiol. 6: $147-217$

Laval, M. (1971). Ultrastructure et mode de nutrition du choanoflagellé Salpingoeca pelagica sp. nov. Comparaison avec les choanocytes des spongiaires. Protistologica 7 : $325-336$
Leadbeater, B. S. C. (1972a). Fine-structural observations on some marine choanoflagellates from the coast of Norway. J. mar biol. Ass. U.K. 52: 67-79

Leadbeater, B. S. C. (1972b). Identification by means of electron microscopy of flagellate nannoplankton from the coast of Norway. Sarsia 49: 107-124

Leadbeater, B. S. C. (1974). Ultrastructural observations on nannoplankton collected from the coast of Yugoslavia and the Bay of Algiers. J. mar. biol. Ass. U.K. 54: 179-196

Leadbeater, B. S. C. (1977). Observations on the life-history and ultrastructure of the marine choanoflagellate Choanoeca perplexa Ellis. J. mar. biol. Ass. U.K. 57 : 285-301

Leadbeater, B. S. C., Morton, C. (1974). A microscopical study of a marine species of Codosiga James-Clark (Choanoflagellata) with special reference to the ingestion of bacteria. Biol. J. Linn. Soc. 6: 337-347

Lighthart, B. (1969). Planktonic and benthic bacteriovorous protozoa at eleven stations in Puget Sound and adjacent Pacific Ocean. J. Fish. Res. Bd Can. 26: 299-304

Lighthill, J. (1976). Flagellar hydrodynamics. SIAM Rev. 18: $161-230$

Lucas, I. A. N. (1968). A new member of the chrysophyceae bearing polymorphic scales. J. mar. biol. Ass. U.K. 48: $437-441$

Mignot, J. P. (1974). Étude ultrastructurale des Bicoeca, protistes flagellés. Protistologica 10: 543-565

Moestrup, Ø., Thomsen, H. A. (1976). Fine structural studies on the flagellate genus Bicoeca. Protistologica 12: $101-120$

Myers, J., Graham, J.-R. (1956). The role of photosynthesis in the physiology of Ochromonas. J. cell. comp. Physiol. 47: $397-414$

Pennick, N. C., Clarke, K. J. (1972). Paraphysomonas butcheri sp. nov. a marine, colourless, scale-bearing member of the chrysophyceae. Br. phycol. J 7: 45-48

Pomeroy, L. R., Johannes, R. E. (1968). Occurrence and respiration of ultraplankton in the upper 500 meters of the ocean. Deep Sea Res. 15: 381-391

Pringsheim, E. G. (1963). Farblose Algen, Gustav Fischer, Jena

Roberts, A. M. (1981). Hydrodynamics of protozoan swimming. In: Levandowsky, M., Hutner, S. H. (eds.) Biochemistry and physiology of protozoa, 2nd ed., Vol. IV Academic Press, New York, pp. 6-66

Rubinow, S. I. (1975). Introduction to mathematical biology, Wiley, New York

Ruinen, J. (1938). Notizen über Salzflagellaten. II. Über die Verbreitung der Salzflagellaten. Arch. Protistenk. 90: $210-258$

Sieburth, J. (1979). Sea microbes, Oxford University Press, New York

Sieburth, J., Smetacek, V., Lenz, J. (1978). Pelagic ecosystem structure: heterotrophic compartments of the plankton and their relationship to plankton size fractions. Limnol. Oceanogr. 23: 1256-1263

Sleigh, M. A. (1964). Flagellar movement of the sessile flagellates Actinomonas, Codonosiga, Monas and Poteriodendron. Q. J. microsc. Sci. 105: 405-41.5

Sorokin, Yu. I. (1977). The heterotrophic phase of plankton succession in the Japan Sea. Mar Biol. 41. 107-117

Spielman, L. A. (1977). Particle capture from low-speed laminar flows. Ann. Rev. Fluid. Mech. 9: 297-319

Swale, E. M. F. (1973). A study of the colourless flagellate Rhynchomonas nasuta (Stokes) Kent. Biol. J. Linn. Soc. 5: 255-264 
Thomsen, H. A. (1973). Studies on marine choanoflagellates I. Ophelia 12: 1-26

Thomsen, H. A. (1975). An ultrastructural survey of the chrysophycean genus Paraphysomonas under natural conditions. Br phycol. J. 10: 113-127

Thomsen, H. A. (1976). Studies on marine choanoflagellates II. Norw. J. Bot. 23: 33-51
Throndsen, J. (1969). Flagellates of Norwegian coastal waters. Nytt Mag. Bot. 16: 161-216

Throndsen, J. (1974). Planktonic choanoflagellates from North Atlantic waters. Sarsia 56: 95-122

Vickerman, K. (1976). The diversity of the kinetoplastid flagellates. In: Lumsden, W. H. R., Evans, D. A. (eds.) Biology of kinetoplastida, Vol. I. Academic Press, New York, pp. 1-34

This paper was submitted to the editor; it was accepted for printing on February 25, 1982 